\title{
ITS-2 sequences-based identification of Trichogramma species in South America
}

\author{
R. P. Almeida ${ }^{*}$ and R. Stouthamer ${ }^{b}$ \\ ${ }^{a}$ Centro Nacional de Pesquisa de Algodão, Empresa Brasileira de Pesquisa Agropecuária - EMBRAPA Algodão, \\ CP 174, CEP 58428-095, Campina Grande, PB, Brazil \\ ${ }^{b}$ Department of Entomology, University of California, Riverside, CA 92521, USA \\ *e-mail: raul.almeida@embrapa.br
}

Received: March 19, 2014 - Accepted: June 11, 2014 - Distributed: November 30, 2015

\begin{abstract}
ITS2 (Internal transcribed spacer 2) sequences have been used in systematic studies and proved to be useful in providing a reliable identification of Trichogramma species. DNAr sequences ranged in size from 379 to $632 \mathrm{bp}$. In eleven T. pretiosum lines Wolbachia-induced parthenogenesis was found for the first time. These thelytokous lines were collected in Peru (9), Colombia (1) and USA (1). A dichotomous key for species identification was built based on the size of the ITS2 PCR product and restriction analysis using three endonucleases (EcoRI, MseI and MaeI). This molecular technique was successfully used to distinguish among seventeen native/introduced Trichogramma species collected in South America.
\end{abstract}

Keywords: molecular markers, ITS-2 sequence, Hymenoptera, egg parasitoid.

\section{Identificação molecular de espécies de Trichogramma na América do Sul via sequenciamento da região ITS-2}

\section{Resumo}

Sequências do Espaço Transcrito Interno 2 (ITS2) têm sido utilizadas em estudos taxonômicos e sua utilidade constatada pela confiabilidade que o método confere à identificação das espécies de Trichogramma. Esta técnica molecular foi bem sucedida em distinguir dezessete espécies nativas e introduzidas de Trichogramma, coletadas na América do Sul. As sequências do DNAr variaram de 379 a 632 pb. Em 11 linhagens de T. pretiosum estudadas, o endosinbionte Wolbachia foi detectado pela primeira vez. Estas linhagens telítocas foram encontradas no Peru (9), Colômbia (1) e Estados Unidos (1). Uma chave dicotômica para identificação de espécies foi construída baseada no tamanho do produto da PCR do ITS2 e em análises de restrição utilizando-se três endonucleases (EcoRI, MseI and MaeI).

Palavras-chave: marcadores moleculares, sequências ITS-2, Hymenoptera, parasitóide de ovos.

\section{Introduction}

Natural enemies of the family Trichogrammatidae are released worldwide against a number of lepidopterous pest on corn, rice, sugar-cane, cotton, vegetables and pines (Smith, 1994; Li, 1994; Grenier, 1994). In the past, most successful biological control agents have been found through trial and error. Nowadays, there is an effort to predict the success of a Trichogramma strain before introductions are made (van Lenteren and Woets, 1988).

Therefore, standard procedures to compare Trichogramma candidates for biological control have been proposed (Hassan, 1994). According to Hassan (1995) before field releases are undertaken, a suitable Trichogramma strain of known qualities should be chosen. The effectiveness of Trichogramma in the field largely depends on its searching behaviour, host preference and tolerance to environmental conditions. However, correct identification of the Trichogramma species that is going to be tested, is a crucial step in any biological control program.

Despite the large improvement with the discovery of male genitalic morphology as species specific characters (Nagarkatti and Nagaraja, 1968, 1971), the identification of these tiny insects remains difficult and requires specialized skills (Pinto and Stouthamer, 1994).

Their small size and lack of morphologically distinct characters has historically been a problem in taxonomic studies. Specimen must be prepared on slides for examination, a time consuming process that requires considerable experience (Platner et al., 1999).

Unfortunately many important species share similar genitalic structures and this has forced workers to continue relying on less dependable characters that often 
are intraspecifically variable and subject to phenotypic plasticity (Pinto et al., 1989; Pinto and Stouthamer, 1994).

To simplify the Trichogramma species identification, several methods have been proposed: (1) Allozymic analysis (Pintureau and Babault, 1980, 1981, 1982; Pintureau and Keita, 1989; Kazmer, 1991; Pinto et al., 1992, 1993; Pintureau, 1993). Esterase electrophoresis has provided consistent results for differentiation of some Trichogramma species (Pinto et al., 1992, 1993; Silva et al., 1999). The limited variation at esterase loci only allows for the differentiation between a limited number of species (Richardson et al., 1986; Pinto and Stouthamer, 1994). In addition the samples subjected to allozyme electrophoresis have to be kept at $-70{ }^{\circ} \mathrm{C}$ to avoid the degeneration of the enzymes; (2) Reproductive compatibility tests (Nagarkatti and Nagaraja, 1968; Pinto et al., 1991; Pintureau, 1991) in which individuals of the unknown species are crossed with individuals of known species status; (3) The DNA sequence of ribosomal spacers (Landry et al., 1993; Orrego and Agudelo-Silva, 1993; Sappal et al., 1995; van Kan et al., 1996, 1997; Pinto et al., 1997); (4) RFLP's of complete mitochondrial genome has also been used for species differentiation (Vanlerberghe-Masutti, 1994). Ribosomal DNA is present in all organisms and is composed of several regions (genes and spacers) that evolve at different rates (Hillis and Dixon, 1991); (5) The internal transcribed spacer regions (ITS- 1 and ITS-2) have been used at species and intraspecific levels of many taxa for distinguishing the different forms (Carbone and Kohn, 1993; Bowles and McManus, 1993; Hsiao et al., 1994; Buckler IV et al., 1997). In insects these sequences have been often used for taxonomic purposes (Campbell et al., 1993; Hoy, 1994; Kuperus and Chapco, 1994; Vogler and DeSalle, 1994; Stouthamer et al., 1999; Silva et al., 1999; Chang et al., 2001; Pinto et al., 2002; Honda et al., 2006; Dem'yanchuk et al., 2008; Kumar et al., 2009; Polaszek et al., 2011; Poorjavad et al., 2012).

Here, we use the ITS2 sequences of Trichogramma species (native or introduced) from South America to develop an identification key. The advantage of this identification system over the morphology-based system is that non-specialists are able to quickly and cheaply identify individual specimens. In addition females can also be identified which is not possible in the morphologically based system. Species found in South America are thelytokous, either because of infection with parthenogenesis inducing Wolbachia (T. pretiosum and T. atopovirilia) (Grenier et al., 1998; Almeida et al., 2001, 2010; Ciociola Junior et al., 2001a) or because of some nuclear genetic factor (T. cacoeciae Marchal) (Stouthamer et al., 1990; Almeida and Stouthamer, 2003). Variation of ITS2 sequence within Trichogramma species is relatively small in comparison to the difference found between species and all morphologically distinct cryptic species are also distinguished by sequence differences (Stouthamer et al., 1999). ITS2 sequences within each species are very similar and there is no evidence for two or more gene families that differ substantially within the genome of a single individual, as has been found in other taxa (Vogler and DeSalle, 1994).

\section{Material and Methods}

\subsection{Trichogramma cultures}

Table 1 lists the Trichogramma species/lines studied here, including their origin, host insect, plant crop, collection date and status as native or introduced.

\subsection{DNA Extraction, PCR Amplification and electrophoresis}

To extract DNA from the different species/lines we used five wasps that were homogenized in $100 \mu \mathrm{L}$ $5 \%$ Chelex-100 and $4 \mu \mathrm{L}$ proteinase $\mathrm{K}(20 \mathrm{mg} / \mathrm{mL})$ and incubated for at least 4 hours at $56{ }^{\circ} \mathrm{C}$, followed by $10 \mathrm{~min}$. at $95^{\circ} \mathrm{C}$. The PCR was performed in a total volume of $50 \mu \mathrm{L}$ using a Techne thermocycler, $5 \mu \mathrm{L}$ DNA template, $5 \mu \mathrm{L}$ 10x PCR-buffer, $1 \mu \mathrm{L}$ dNTP's (each in a $10 \mathrm{mM}$ concentration), $1 \mu \mathrm{L}$ forward and reverse primers (ITS2-forward: 5' -TGTGAACTGCAG GACACATG-3' located in the $5.8 \mathrm{~S}$ region of the rDNA; ITS2-reverse: 5' -GTCTTGCC TGCTCTGCTCTGAG-3' located in the 28S region of the rDNA (Stouthamer et al., 1999); $0.14 \mu \mathrm{L}$ TAQ polymerase ( 5 units $/ \mu \mathrm{L})$ and $36.86 \mu \mathrm{L}$ of sterile distilled water. The cycling program was $3 \mathrm{~min}$. at $94{ }^{\circ} \mathrm{C}$ followed by 33 cycles of 40 seconds at $94{ }^{\circ} \mathrm{C}$, 45 second at $53{ }^{\circ} \mathrm{C}$ and 45 seconds at $72{ }^{\circ} \mathrm{C}$ with 5 min. at $72{ }^{\circ} \mathrm{C}$ after the last cycle.

\subsection{Cloning, sequencing and alignments}

Following electrophoresis, PCR products were purified with a QIAquick PCR purification kit (Qiagen $\left.{ }^{\circledR}\right)$. After the purification the PCR products were ligated into a Pgem- $\mathrm{T}^{\circledast}$ Vector (Promega), $2 \mu \mathrm{L}$ of the ligation mix was transformed in the heat shock cells of DH5- $\alpha$ Escherichia coli and plated on a LB agar medium containing Ampicilin, XGAL and IPTG. The plates were incubated overnight at $37^{\circ} \mathrm{C}$. The next day, white colonies were picked up with a sterile toothpick from the plates and placed into tubes containing $3.0 \mathrm{~mL}$ of LB liquid medium and $3 \mu \mathrm{L}$ Ampicilin and put to grow up overnight in a shaker set to $250 \mathrm{rpm}$ at $37^{\circ} \mathrm{C}$. To confirm that the correct piece of DNA had been cloned, a PCR reaction with a template extracted from the bacterial culture was added to $100 \mu \mathrm{L} \mathrm{5 \%}$

Chelex- 100 and incubated for $15 \mathrm{~min}$. at $60^{\circ} \mathrm{C}$ followed by $5 \mathrm{~min}$. at $95^{\circ} \mathrm{C}$. The PCR was performed with $5 \mu \mathrm{L}$ of this template as described before. If indeed an ITS2 had been cloned, $850 \mu \mathrm{L}$ of the bacteria culture was added to $150 \mu \mathrm{L}$ of $87 \%$ glycerol and stored at $-80^{\circ} \mathrm{C}$. The rest of the culture was used in a QIAprep Miniprep kit (Qiagen ${ }^{\circledR}$ ) to purify the plasmid, which was used for the sequencing in an Applied Biosystems automatic sequencer. Trichogramma sequences were aligned manually using the ESEE 3.0s sequence editor (Cabot, 1995).

\subsection{Thelytoky in Trichogramma}

For detection of thelytoky caused by Wolbachia infection, specific primers for DNA amplification of the $w s p$ region of Wolbachia were used: $w s p$-Forward primer 5'TGGTCCAATAAGTGATGAAGAAAC-3' and 


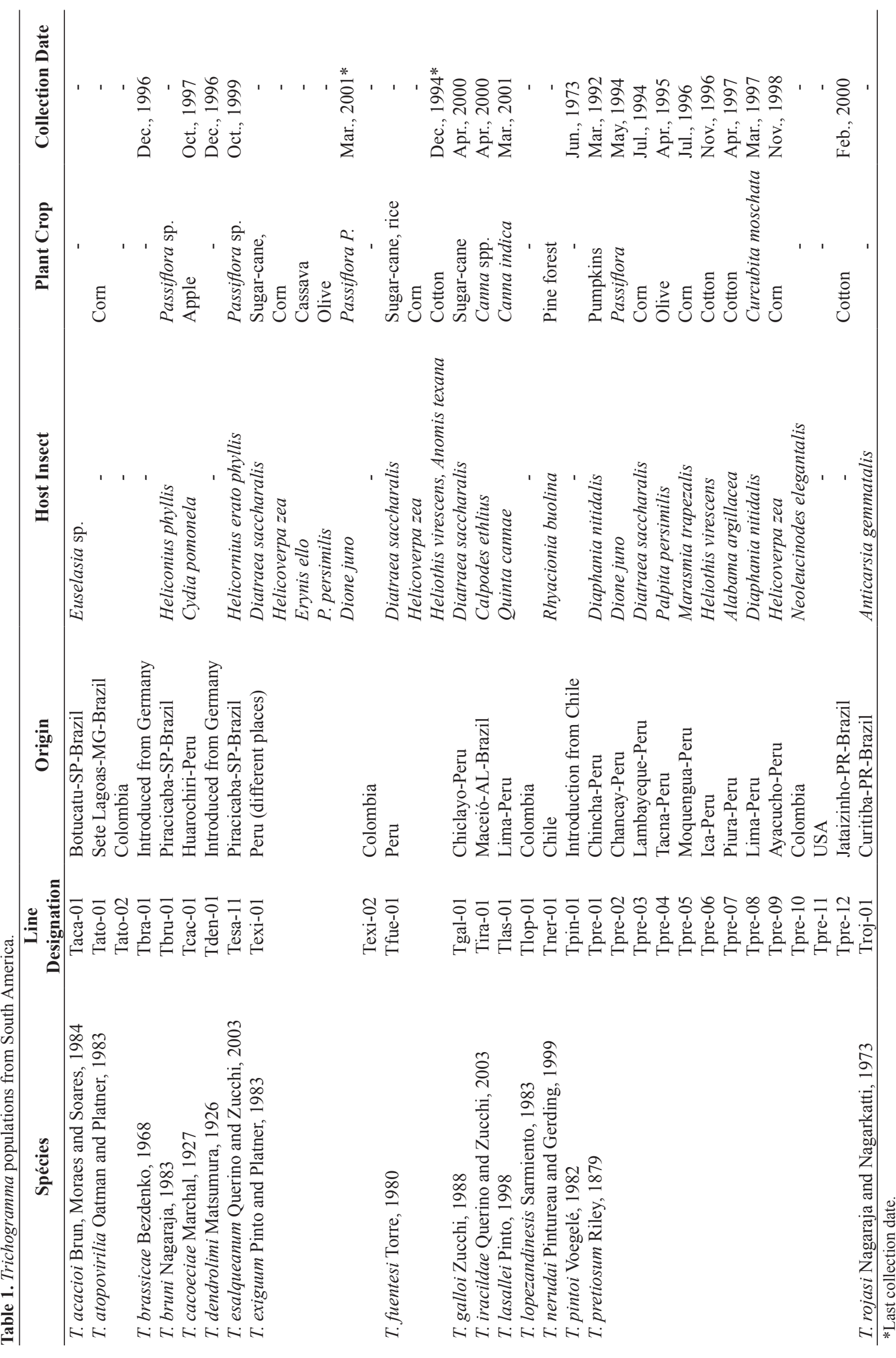


wsp-Reverse 5' -AAAAATTAAACGCTACTC CA-3' (Braig et al., 1998). These primers amplify 554bp of the wsp gene. The cycling program was $3 \mathrm{~min}$. at $94{ }^{\circ} \mathrm{C}$ followed by 40 cycles of $1 \mathrm{~min}$. at $94^{\circ} \mathrm{C}, 1 \mathrm{~min}$. at $50^{\circ} \mathrm{C}$ and $1 \mathrm{~min}$. at $72{ }^{\circ} \mathrm{C}$ with $5 \mathrm{~min}$. at $72^{\circ} \mathrm{C}$ after the last cycle.

\subsection{Molecular key}

A molecular key for separating Trichogramma species was constructed based on the size and the fragment profile following restriction with different restriction enzymes. Initially we determined ITS2 sequences of all species and lines, subsequently we first tried to distinguish the different species based on the size of the PCR product. Species with similar sized PCR products were distinguished by selecting restriction enzymes that would generate differently sized in restriction fragments. To predict the fragment sizes to be expected with different enzymes we use the program Webcutter 2.0 (Heiman, 1997). Three restriction enzymes were used (EcoRI, MseI and MaeI).

\section{Results}

Seventeen native and introduced Trichogramma species collected in South America were identified based on ITS2 sequences. In total, thirty lines were studied (Table 1).
Seventeen lines were recognised as arrhenotokous and thirteen as thelytokous. Twelve out of thirteen thelytokous lines studied here carry the Wolbachia symbiont. In T. cacoeciae, parthenogenesis was not caused by Wolbachia infection (Stouthamer et al., 1990; Almeida and Stouthamer, 2003). For all other parthenogenetic lines, Wolbachia detection was possible by using specific primers of the $w s p$ region. In all thelytokous species/lines no male was found, except for T. atopovirilia (culture form Brazil) and T. pretiosum (culture from the Entomology Lab., California University, Riverside-USA) in which few males were present.

Complete ITS2 sequences have been deposited in GenBank (Table 2). Trichogramma species were identified by (1) morphological identification: T. atopovirilia, line Tato-01, (Dr. Américo I. Ciociola Junior - EPAMIG, Brazil, personal comunication), T. lopezandinensis and T. fuentesi (Dr. Ranyse B.Q. da Silva-ESALQ/USP, Brazil, personal communication); (2) by comparison with ITS2 sequences from the GenBank: T. pintoi, T. lasallei, T. cacoeciae, T. galloi, T. pretiosum, T. brassicae, T. dendrolimi and T. exiguum; or (3) by comparison with sequences not published yet: T. nerudai. T. rojasi and T. acacioi lines were the same as those used by Ciociola Junior et al. (2001b). Two new species from Brazil (T. iracildae and

Table 2. Line designation, reproduction mode, genbank accession number of the Trichogramma species and size of the ITS2 and PCR product (bp).

\begin{tabular}{|c|c|c|c|c|}
\hline Line Designation & Reproduction Mode & Acession Number & ITS-2 Product & PCR product \\
\hline Tner-01 & Arrhenotoky & AY182756 & 632 & 746 \\
\hline Tpin-01 & Arrhenotoky & AY182757 & 581 & 695 \\
\hline Tato-01 & Thelytoky & AY182758 & 565 & 680 \\
\hline Tato-02 & Arrhenotoky & AY182759 & 561 & 675 \\
\hline Taca-01 & Arrhenotoky & - & 559 & 674 \\
\hline Tbru-01 & Arrhenotoky & AY187263 & 536 & 650 \\
\hline Troj-01 & Arrhenotoky & - & 524 & 638 \\
\hline Tira-01 & Arrhenotoky & AY182760 & 522 & 636 \\
\hline Tlop-01 & Arrhenotoky & AY182761 & 509 & 623 \\
\hline Tlas-01 & Arrhenotoky & AY182762 & 485 & 599 \\
\hline Tesa-11 & Arrhenotoky & AY182763 & 379 & 493 \\
\hline Tcac-01 & Thelytoky & AY166700 & 460 & 574 \\
\hline Tgal-01 & Arrhenotoky & AY182764 & 445 & 560 \\
\hline Tfue- 01 & Arrhenotoky & AY182765 & 437 & 553 \\
\hline Tpre-01 & Thelytoky & AY182770 & 410 & 524 \\
\hline Tpre- 02 & Thelytoky & AY182771 & 410 & 524 \\
\hline Tpre-03 & Thelytoky & AY182772 & 415 & 529 \\
\hline Tpre-04 & Thelytoky & AY182773 & 410 & 524 \\
\hline Tpre-05 & Thelytoky & AY184958 & 410 & 524 \\
\hline Tpre-06 & Thelytoky & AY184959 & 410 & 524 \\
\hline Tpre-07 & Thelytoky & AY187259 & 415 & 529 \\
\hline Tpre-08 & Thelytoky & AY184960 & 410 & 524 \\
\hline Tpre-09 & Thelytoky & AY184961 & 410 & 524 \\
\hline Tpre-10 & Thelytoky & AY187260 & 412 & 526 \\
\hline Tpre-11 & Thelytoky & AY187261 & 413 & 527 \\
\hline Tpre-12 & Arrhenotoky & AY187262 & 412 & 526 \\
\hline Tbra-01 & Arrhenotoky & AY182766 & 406 & 520 \\
\hline Tden-01 & Arrhenotoky & AY182767 & 403 & 519 \\
\hline Texi-01 & Arrhenotoky & AY182768 & 383 & 497 \\
\hline Texi-02 & Arrhenotoky & AY182769 & 381 & 496 \\
\hline
\end{tabular}


T. esalqueanum) sequenced here were recorded by Querino and Zucchi (2003).

An identification key was constructed for these species using as two characters of the PCR product its size and the restriction patterns generation using the three restriction enzymes EcoRI, MseI and MaeI (Table 3). España-Luna et al. (2008) used two restricion enzymes (EcoRI and AluI) for distinguishing six Trichogramma species from each other in Mexico. Sumer et al. (2009) used three restricion enzymes (MnlI, MseI and DraI) for distinguishing six Trichogramma species from each other in agricultural settings around the Mediterranean.

Here, ITS2 product size of the seventeen studied species ranged from 379 to $632 \mathrm{bp}$ and sequences differ from each other consistently. In our sample the size of the ITS 2 product alone could not identify the species,

Table 3. Molecular key for Trichogramma species recognition based on the size of the PCR product and species-specific banding pattern.

1. Size of the PCR product $<620 \mathrm{bp}$

Size of the PCR product $>620 \mathrm{bp}$

2. Size of the PCR product $<550 \mathrm{bp}$

Size of the PCR product $>550 \mathrm{bp}$

3. Size of the PCR product $\leq 500 \mathrm{bp}$

4. PCR product cut by MseI ca. 280 and 191 bp PCR product not cut by MseI

5. PCR product cut by EcoRI

6. PCR product cut by MseI ca. $441 \mathrm{bp}$

T. dendrolimi PCR product cut by MseI ca. 411 bp

T. brassicae

7. PCR product not cut by MseI 8 PCR product cut by MseI

8. PCR product cut by MaeI ca. 267 and 218 bp

9. PCR product cut by EcoRI ca. 346 and 228 bp

T. cacoeciae PCR product not cut by EcoRI

10. Size of the PCR product $<670 \mathrm{bp}$

11. PCR product not cut by MseI

12. PCR product cut by MaeI ca. 480 and 143 bp PCR product cut by MaeI ca. 517 bp

14. Size of the PCR product $>700 \mathrm{bp}$

15. PCR product cut by EcoRI 
but cutting the ITS2 product of the different species using only three restriction enzymes (EcoRI, MseI and MaeI) enabled us to identify all species (Table 3). For instance the variation in the size of ITS2 was evaluated in T. atopovirilia, T. exiguum and T. pretiosum. The length of the complete sequences found for $T$. pretiosum lines all ranged from 410 to $415 \mathrm{bp}$ (Table 3), for T. atopovirilia (561-565 bp) and for T. exiguum (381-383 bp). In general, variation was limited to the number of microsatellite repeat stretches found in the ITS2 sequences.

\section{Discussion}

Distributed worldwide, Trichogramma are known with circa of 210 species (Pinto, 2006). In North America, Central America and South America are recorded respectively 60, 21 ad 41 species. Considering only the presence of native species in South America, Brazil has the largest number of known species (26) followed by Venezuela (13), Colombia (9), Peru (7), Uruquay (6), Chile (4) and Ecuador and Paraguay (2) (Zucchi et al., 2010; Querino and Zucchi, 2011).

In T. atopovirilia the presence of Wolbachia was recorded for the first time in Brazil by Ciociola Junior et al. (2001a). In all T. pretiosum lines studied here Wolbachia infection was reported for the first time. In South America, Wolbachia infection has been reported in T. pretiosum from Uruguay (Grenier et al., 1998) and from Brazil (Almeida et al., 2001).

The usefulness of endonucleases analysis for distinguishing Trichogramma species was shown by Stouthamer et al. (1999), Silva et al. (1999) and Pinto et al. (2002). How reliable are such molecular keys that are based in some cases on the sequence of only a few lines? The experience with other Trichogramma species is that the intraspecific variation in the ITS2 is rather limited. The variation in number of microsatellite repeats seems to be common in ITS sequences, similar microsatellite variation was for instance also found in Eriophyid mites (Fenton et al., 1997). The range obtained here confirms the low intraspecific variation in the ITS2 length detected by Stouthamer et al. (1999) and Silva et al. (1999). According to Stouthamer et al. (1999) ITS2 can be used for species identification in Trichogramma because the sequence variation within species is small relative to the difference found between species. All morphologically distinct cryptic species are also distinguished by sequence differences, however in the morphologically indistinguishable species North American species T. minutum Riley and T. platneri Nagarkatti no consistent differences were found in their ITS2 sequences (Stouthamer et al., 2000). In this case the ITS2 did not improve upon the morphologically based system. A potential weakness of an ITS2 based molecular key as presented here is that in some cases the key relies on either a restriction of an ITS2 by a particular enzyme or the lack thereof. When no restriction digestion is found it is not immediately clear if the endonuclease worked or if the products lack the restriction site (Stouthamer et al., 1999).
It is important to run along a positive control to assure that the restriction reactions work. Molecular laboratories with basic infrastructure can perform PCR amplifications followed by restriction digestions and DNA can be extracted from living, frozen, ethanol-preserved or dried material (Post et al., 1993; van Kan et al., 1996; Ciociola Junior et al., 2000). Just as in case of morphological keys, molecular keys will only be completely reliable once all species of a region are known.

This study together with previous studies (Stouthamer et al., 1999; Silva et al., 1999; Ciociola Junior et al., 2001b) shows the utility of ITS2 sequences in Trichogramma identification. The molecular technique used in this study will be of a great utility in a near future for sequencing species already classified but not sequenced yet from South America. We also expect that with this technique new species will be soon discovered due to the high diversity of Trichogramma host insects in this region. The small number of species found until now is caused by the very limited activities to collect species of Trichogramma. In addition, most of the host species collected were restricted to insects of economic importance. Also there are only a few taxonomists specialized in identifying Trichogramma species using morphological features. Identification by the combination of morphological characters and molecular technique will be of extreme importance for a successful systematic analysis of this group.

\section{Acknowledgements}

The authors are thankful to Joop van Lenteren for his valuable comments on the manuscript, and to all those who sent Trichogramma species: Americo I. Ciociola Junior (EPAMIG-Brazil), Aristóbolo Lopez-Avila (CORPOICA-Colombia), Celso L. Hohmann (IAPAR-Brazil), Eduardo N. Botto (IMYZA (CNIA), INTA-Argentina), Mary Whu (SESANA-Peru), Ranyse B.Q. da Silva (ESAlQ-USP-Brazil) and Gary A. Platner (Universisty of California-Riverside-USA). This molecular biology research was financially supported by Embrapa (PRODETAB).

\section{References}

ALMEIDA, R.P. and STOUTHAMER, R., 2003. Molecular identification of Trichogramma cacoecieae Marchal (Hymenoptera: Trichogrammatidae): a new record for Peru. Neotropical Entomology, vol. 32, no. 2, pp. 269-272. http://dx.doi.org/10.1590/S1519$566 \times 2003000200011$.

ALMEIDA, R.P., CIOCIOLA JUNIOR, A.I. and STOUTHAMER, R., 2001. Wolbachia-induced parthenogenesis: the first report in a Brazilian Trichogramma pretiosum population. Proceedings of the Section Experimental and Applied Entomology, vol. 12, pp. 41-44.

ALMEIDA, R.P., VAN LENTEREN, J.C. and STOUTHAMER, R., 2010. Does Wolbachia infection affect Trichogramma atopovirilia behaviour? Brazilian Journal of Biology = Revista Brasileira de Biologia, vol. 70, no. 2, pp. 435-442. http://dx.doi.org/10.1590/ S1519-69842010005000016. PMid:20379652. 
BOWLES, J. and MCMANUS, D.P., 1993. Rapid discrimination of Echinococcus species and strains using a polymerase chain reactionbased RFLP method. Molecular and Biochemical Parasitology, vol. 57, no. 2, pp. 231-239. http://dx.doi.org/10.1016/01666851(93)90199-8. PMid:8094539.

BRAIG, H.R., ZHOU, W., DOBSON, S. and O'NEILL, S.L., 1998. Cloning and characterization of a gene encoding the major surface protein of the bacterial ensosymbiont Wolbachia pipientis. Journal of Bacteriology, vol. 180, no. 9, pp. 2373-2378. PMid:9573188.

BUCKLER IV, E.S., IPPOLITO, A. and HOLTSFORD, T.P., 1997. The evolution of ribosomal DNA: divergent paralogues and phylogenetic implications. Genetics, vol. 145, no. 3, pp. 821-832. PMid:9055091.

CABOT, E.L., 1995. The Eyeball Sequence Editor (ESEE). Version 3.0s. Rochester: Department of Biology, University of Rochester.

CAMPBELL, B.C., STEFFEN-CAMPBELL, J.D. and WERREN, J.H., 1993. Phylogeny of the Nasonia species complex (Hymenoptera: Pteromalidae) inferred from an internal transcribed spacer (ITS2) and 28S rDNA sequences. Insect Molecular Biology, vol. 2, no. 4, pp. 225-237. http://dx.doi.org/10.1111/j.1365-2583.1994. tb00142.x. PMid:9087560.

CARBONE, I. and KOHN, L., 1993. Ribosomal DNA sequence divergence within transcribed spacer 1 of the Sclerotiniaceae. Mycologia, vol. 85 , no. 3, pp. 415-427. http://dx.doi.org/10.2307/3760703.

CHANG, S.C., HU, N.T., HSIN, C.Y. and SUN, C.N., 2001. Characterization of differences between two Trichogramma wasps by molecular markers. Biological Control, vol. 21, no. 1, pp. 75-78. http://dx.doi.org/10.1006/bcon.2001.0924.

CIOCIOLA JUNIOR, A.I., ALMEIDA, R.P. and STOUTHAMER, R., 2000. Does degradation of DNA in dead Trichogramma individuals lead to failure of their identification using PCR? Proceedings of the Section Experimental and Applied Entomology, vol. 11 , pp. 33-36

CIOCIOLA JUNIOR, A.I., ALMEIDA, R.P., ZUCCHI, R.A. and STOUTHAMER, R., 2001a. Detecção de Wolbachia em uma população telítoca de Trichogramma atopovirilia Oatman and Platner (Hymenoptera: Trichogrammatidae) via PCR com o Primer Específico wsp. Neotropical Entomology, vol. 30, no. 3, pp. 489-491. http://dx.doi.org/10.1590/S1519-566X2001000300027.

CIOCIOLA JUNIOR, A.I., ZUCCHI, R.A. and STOUTHAMER, R., 2001b. Molecular key to seven brazilian species of Trichogramma (Hymenoptera: Trichogrammatidae) using sequences of the ITS2 region and restriction analysis. Neotropical Entomology, vol. 30, no. 2, pp. 259-262. http://dx.doi.org/10.1590/S1519566X2001000200008.

DEM'YANCHUK, N.P., OBLAP, R.V., NOVAK, N.B. and MEL'NICHUK, M.D., 2008. Molecular-genetics study of entomophages of the genus Trichogramma Westw. Cytology and Genetics, vol. 42, no. 4, pp. 263-266. http://dx.doi.org/10.3103/ S0095452708040087.

ESPAÑA-LUNA, M.P., GONZÁLEZ-HERNÁNDEZ, A., ALVARADO-GÓMEZ, O.G. and LOZANO-GUTIÉRREZ, J., 2008. Identificación molecular de especies crípticas de Trichogramma Westwood (Hymenoptera: Trichogrammatidae) de importancia agrícola en México. Acta Zoológica Mexicana, vol. 24, pp. 1-14.

FENTON, B., MALLOCH, G. and MOXEY, E., 1997. Analysis of eriophyid mite rDNA internal transcribed spaces sequences reveals variable simple sequence repeats. Insect Molecular Biology, vol. 6, pp. 23-32.
GRENIER, S., 1994. Rearing of Trichogramma and other egg parasitoids on artificial diets. In: E. WAJNBERG and S.A. HASSAN, eds. Biological control with egg parasitoids. Wallingford: CAB International, pp. 73-92.

GRENIER, S., BERNARD, P., HEDDI, A., LASSABLIERE, F., JAGER, C., LOUIS, C. and KHATCHADOURIAN, C., 1998. Successful horizontal transfer of Wolbachia symbionts between Trichogramma wasps. Proceedings: Biological Sciences, vol. 265, no. 1404, pp. 1441-1445. http://dx.doi.org/10.1098/rspb.1998.0455.

HASSAN, S.A., 1994. Strategies to select Trichogramma species for use in biological control. In: E. WAJNBERG and S.A. HASSAN, eds. Biological control with egg parasitoids. Wallingford: $\mathrm{CAB}$ International, pp. 55-71.

HASSAN, S.A., 1995. Introduction to the "Effectiviness and Assessment" session. Les Colloq del'INRA, vol. 73, pp. 107-111.

HEIMAN, M., 1997 [accessed 25 June 2002]. Webcutter 2.0 [software]. New Haven. Available from: http://www.firstmarket. com/cutter/cut2.html

HILLIS, D.M. and DIXON, M.T., 1991. Ribosomal DNA: molecular evolution and phylogenetic inference. The Quarterly Review of Biology, vol. 66, no. 4, pp. 411-453. http://dx.doi. org/10.1086/417338. PMid:1784710.

HONDA, J.Y., TAYLOR, L., RODRIGUEZ, J., YASHIRO, N. and HIROSE, Y., 2006. A taxonomic review of the Japanese Trichogramma (Hymenoptera: Trichogrammatidae) with descriptions of three new species. Applied Entomology and Zoology, vol. 41, no. 2, pp. 247-267. http://dx.doi.org/10.1303/aez.2006.247.

HOY, M.A., 1994. Insect molecular genetics: an introduction to principles and applications. San Diego: Academic Press. 546 p.

HSIAO, C., CHATTERTON, N.J., ASAY, K.H. and JENSEN, K.B., 1994. Phylogenetic relationships of 10 grass species: an assessment of phylogenetic utility of the internal transcribed spacer region in nuclear ribosomal DNA in monocots. Genome, vol. 37, no. 1, pp. 112-120. http://dx.doi.org/10.1139/g94-014. PMid:8181731.

KAZMER, D.J., 1991. Isoelectric focusing procedures for the analysis of allozymic variation in minute arthropods. Annals of the Entomological Society of America, vol. 84, no. 3, pp. 332-339. http://dx.doi.org/10.1093/aesa/84.3.332.

KUMAR, G.A., JALALI, S.K., VENKATESAN, T., STOUTHAMER, R., NIRANJANA, P. and LALITHA, Y., 2009. Internal transcribed spacer-2 restriction fragment length polymorphism (ITS-2-RFLP) tool to differentiate some exotic andindigenous trichogrammatid egg parasitoids in India. Biological Control, vol. 49, no. 3, pp. 207-213. http://dx.doi.org/10.1016/j.biocontrol.2009.02.010.

KUPERUS, W.R. and CHAPCO, W., 1994. Usefulness of internal transcribed spacer regions of ribosomal DNA in Melanopline (Orthoptera, Acrididae) systematics. Annals of the Entomological Society of America, vol. 87, no. 6, pp. 751-754. http://dx.doi. org/10.1093/aesa/87.6.751.

LANDRY, B.S., DEXTRAZE, L. and BOIVIN, G., 1993. Random amplified polymorphic DNA markers for DNA fingerprinting and genetic variability assessment of minute parasitic wasp species (Hymenoptera: Mymaridae and Trichogrammatidae) used in biological control programs of phytophagous insects. Genome, vol. 36, no. 3, pp. 580-587. http://dx.doi.org/10.1139/g93-078. PMid:8349128.

LI, L., 1994. Worldwide use of Trichogramma for biological control on different crops: a survey. In: E. WAJNBERG and 
S.A. HASSAN, eds. Biological control with egg parasitoids. Wallingford: CAB International, pp. 37-53.

NAGARKATTI, S. and NAGARAJA, H., 1968. Biosystematic studies on Trichogramma species. I. Experimental hybridization between Trichogramma australicum Girault, Tevanescens Westw. and T. minutum Riley. Commonwealth Institute of Biological Control Technical Bulletin, vol. 10, pp. 81-96.

NAGARKATTI, S. and NAGARAJA, H., 1971. Redescription of some known species of Trichogramma (Hym. Trichogrammatidae), showing the importance of the male genitalia as a diagnostic character. Bulletin of Entomological Research, vol. 61, no. 1, pp. 13-21. http://dx.doi.org/10.1017/S0007485300057412.

ORREGO, C. and AGUDELO-SILVA, F., 1993. Genetic variation in the parasitoid wasp Trichogramma (Hymenoptera, Trichogrammatidae) revealed by DNA amplification of a section of the nuclear ribosomal repeat. The Florida Entomologist, vol. 76, no. 3, pp. 519-524. http://dx.doi.org/10.2307/3495653.

PINTO, J.D. and STOUTHAMER, R., 1994. Systematics of the Trichogrammatidae with emphasis on Trichogramma. In: E. WAJNBERG and S.A. HASSAN, eds. Biological control with egg parasitoids. Wallingford: CAB International, pp. 1-36.

PINTO, J.D., 2006. A review of the New World genera of Trichogrammatidae (Hymenoptera). Journal of Hymenoptera Research, vol. 15, pp. 38-163.

PINTO, J.D., KAZMER, D.J., PLATNER, G.R. and SASSAMAN, C.A., 1992. Taxonomy of the Trichogramma minutum complex (Hymenoptera: Trichogrammatidae): allozymic variation and its relationship to reproductive and geographic data. Annals of the Entomological Society of America, vol. 85, no. 4, pp. 413-422. http://dx.doi.org/10.1093/aesa/85.4.413.

PINTO, J.D., KOOPMANSCHAP, A.B., PLATNER, G.R. and STOUTHAMER, R., 2002. The North American Trichogramma (Hymenoptera: Trichogrammatidae) parasitizing certain Tortricidae (Lepidoptera) on apple and pear, with ITS2 DNA characterizations and description of a new species. Biological Control, vol. 23, no. 2, pp. 134-142. http://dx.doi.org/10.1006/bcon.2001.0995.

PINTO, J.D., PLATNER, G.R. and SASSAMAN, C.A., 1993. Electrophoretic study of two closely related of North American Trichogramma: T. pretiosum and T. deion. Annals of the Entomological Society of America, vol. 86, no. 6, pp. 702-709. http://dx.doi.org/10.1093/aesa/86.6.702.

PINTO, J.D., STOUTHAMER, R. and PLATNER, G.R., 1997. A new cryptic species of Trichogramma (Hymenoptera: Trichogrammatidae) from the Mojave desert of California as determined by morphological, reproductive and molecular data. Proceedings of the Entomological Society of Washington, vol. 99 , pp. 238-247.

PINTO, J.D., STOUTHAMER, R., PLATNER, G.R. and OATMAN, E.R., 1991. Variation in reproductive compatibility in Trichogramma and its taxonomic significance (Hymenoptera: Trichogrammatidae). Annals of the Entomological Society of America, vol. 84, no. 1, pp. 37-46. http://dx.doi.org/10.1093/ aesa/84.1.37.

PINTO, J.D., VELTEN, R.K., PLATNER, G.R. and OATMAN, E.R., 1989. Phenotipic plasticity and taxonomic characters in Trichogramma. Annals of the Entomological Society of America, vol. 85, pp. 413-422. http://dx.doi.org/10.1093/aesa/85.4.413.

PINTUREAU, B. and BABAULT, M., 1980. Comparaison des estérases chez 19 souches de Trichogramma (Hym., Trichogrammatidae) appartenant au groupe d'espèces evanescens. Archives de Zoologie Expérimentale et Générale, vol. 121, pp. 249-260.

PINTUREAU, B. and BABAULT, M., 1981. Caractérisation enzymatique de Trichogramma evanescens et de T. maidis (Hym., Trichogrammatidae); étude des hybrides. Entomophaga, vol. 26, no. 1, pp. 11-22. http://dx.doi.org/10.1007/BF02371830.

PINTUREAU, B. and BABAULT, M., 1982. Comparison des enzymes chez 10 souches de Trichogramma (Hym., Trichogrammatidae). Colloques de l'INRA, vol. 9, pp. 31-44.

PINTUREAU, B. and KEITA, F.B., 1989. Nouvelles données sur les estérases des Trichogrammes. Biochemical Systematics and Ecology, vol. 17, no. 7-8, pp. 603-608. http://dx.doi. org/10.1016/0305-1978(89)90106-3.

PINTUREAU, B., 1991. Indices d'isolement reproductif entre espèces proches de Trichogrammes (Hym.: Trichogrammatidae). Annales de la Société Entomologique de France, vol. 27, pp. 379-392.

PINTUREAU, B., 1993. Enzymatic analysis of the genus Trichogramma (Hym.: Trichogrammatidae) in Europe. Entomophaga, vol. 38, no. 3, pp. 411-431. http://dx.doi.org/10.1007/BF02374459.

PLATNER, G.R., VELTEN, R.K., PLANOUTENE, M. and PINTO, J.D., 1999. Slide-mounting techniquesfor Trichogramma (Trichogrammatidae) and other minute parasitic Hymenoptera. Entomological News, vol. 110, pp. 56-64.

POLASZEK, A., RUGMAN-JONES, P.F., STOUTHAMER, R., HERNANDEZ-SUAREZ, E., CABELLO, T. and PEREZ, M., 2011. Molecular and morphological diagnoses of five species of Trichogramma: biological control agents of Chrysodeixis chalcites (Lepidoptera: Noctuidae) and Tuta absoluta (Lepidoptera: Gelechiidae) in the Canary Islands. BioControl, vol. 57, no. 1, pp. 21-35. http://dx.doi.org/10.1007/s10526-011-9361-y.

POORJAVAD, N., GOLDANSAZ, S.H., MACHTELINCKX, T., TIRRY, L., STOUTHAMER, R. and VAN LEEUWEN, T., 2012. Iranian Trichogramma: ITS2 DNA characterization and natural Wolbachia infection. BioControl, vol. 57, no. 3, pp. 361-374. http://dx.doi.org/10.1007/s10526-011-9397-z.

POST, R.J., FLOOK, P.K. and MILLEST, A.L., 1993. Methods for the preservation of insects for DNA studies. Biochemical Systematics and Ecology, vol. 21, no. 1, pp. 85-92. http://dx.doi. org/10.1016/0305-1978(93)90012-G.

QUERINO, R.B. and ZUCCHI, R.A., 2003. New species of Trichogramma Westwood (Hymenoptera: Trichogrammatidae) associated with lepidopterous eggs in Brazil. Zootaxa, vol. 163, pp. 1-10.

QUERINO, R.B. and ZUCCHI, R.A., 2011. Guia de identificação de Trichogramma para o Brasil. 1st ed. Brasília: Embrapa. 103 p. Informação Tecnológica, vol. 1.

RICHARDSON, B.J., BAVERSTOCK, P.R. and ADAMS, M., 1986. Allozyme electrophoresis: a handbook for animal systematics and population studies. Sydney: Academic Press Australia. 410 p.

SAPPAL, N.P., JENG, R.S., HUBBES, M. and LIU, F., 1995. Restriction fragment length polymorphisms in polymerase chain reaction amplified ribosomal DNAs of three Trichogramma (Hymenoptera: Trichogrammatidae) species. Genome, vol. 38, no. 3, pp. 419-425. http://dx.doi.org/10.1139/g95-055. PMid:7557356.

SILVA, I.M.M.S., HONDA, J., VAN KAN, F., HU, S.J., NETO, L., PINTUREAU, B. and STOUTHAMER, R., 1999. Molecular differentiation of five Trichogramma species occurring in Portugal. 
Biological Control, vol. 16, no. 2, pp. 177-184. http://dx.doi. org/10.1006/bcon.1999.0755.

SMITH, S.M., 1994. Methods and timing of releases of Trichogramma to control lepidopterous pest. In: E. WAJNBERG and S.A. HASSAN, eds. Biological control with egg parasitoids. Wallingford: CAB International, pp. 113-144.

STOUTHAMER, R., GAI, Y., KOOPMANSCHAP, A.B., PLATNER, G.R. and PINTO, J.D., 2000. ITS-2 sequences do not differ for the closely related species Trichogramma minutum and T. platneri. Entomologia Experimentalis et Applicata, vol. 95, no. 1, pp. 105-111. http://dx.doi.org/10.1046/j.1570-7458.2000.00647.x.

STOUTHAMER, R., HU, J., VAN KAN, F.J.P.M., PLATNER, G.R. and PINTO, J.D., 1999. The utility of internally transcribed spacer 2 DNA sequences of the nuclear ribosomal gene for distinguishing sibling species of Trichogramma. BioControl, vol. 43, no. 4, pp. 421-440. http://dx.doi.org/10.1023/A:1009937108715.

STOUTHAMER, R., PINTO, J.D., PLATNER, G.R. and LUCK, R.F., 1990. Taxonomic status of thelytokous forms of Trichogramma (Hymenoptera: Trichogrammatidae). Annals of the Entomological Society of America, vol. 83, no. 3, pp. 475-581. http://dx.doi. org/10.1093/aesa/83.3.475.

SUMER, F., TUNCBILEK, A.S., OZTEMIZ, S., PINTUREAU, B., RUGMAN-JONES, P. and STOUTHAMER, R., 2009. A molecular key to the common species of Trichogramma of the Mediterranean region. BioControl, vol. 54, no. 5, pp. 617-624. http://dx.doi.org/10.1007/s10526-009-9219-8.
VAN KAN, F.J.P.M., HONDA, J., PINTO, J.D. and STOUTHAMER, R., 1997. Molecular based techniques for Trichogramma identification. Proceedings of the Section Experimental and Applied Entomology, vol. 8, pp. 59-62.

VAN KAN, F.J.P.M., SILVA, I.M.M.S., SCHILTHUIZEN, M., PINTO, J.D. and STOUTHAMER, R., 1996. Use of DNA-based methods for the identification of minute wasps of the genus Trichogramma. Proceedings of the Section Experimental and Applied Entomology, vol. 7, pp. 233-238.

VAN LENTEREN, J.C. and WOETS, J., 1988. Biological and integrated pest control in greenhouses. Annual Review of Entomology, vol. 33, no. 1, pp. 239-269. http://dx.doi.org/10.1146/ annurev.en.33.010188.001323.

VANLERBERGHE-MASUTTI, F., 1994. Molecular identification and phylogeny of parasitic wasp species (Hymenoptera: Trichogrammatidae) by mitochondrial DNA RFLP and RAPD markers. Insect Molecular Biology, vol. 3, no. 4, pp. 229-237. http:// dx.doi.org/10.1111/j.1365-2583.1994.tb00171.x. PMid:7704306.

VOGLER, A.P. and DESALLE, R., 1994. Evolution and phylogenetic information content of the ITS-1 region in the tiger beetle Cincidela dorsalis. Molecular Biology and Evolution, vol. 11, no. 3, pp. 393-405. PMid:8015434.

ZUCCHI, R.A., QUERINO, R.B. and MONTEIRO, R.C., 2010. Diversity and hosts of Trichogramma in the New World, with emphasis in South America. In: F.L. CONSOLI, J.R.P. PARRA and R.A. ZUCCHI, orgs. Egg parasitoids in agroecosystems with emphasis on Trichogramma. 1st ed. New York: Springer, vol. 1, pp. 219-236. 